\section{PROMOTING EFFECTS OF ABILITIES WHILE ENHANCING PROBABILITY OF COLLEGE-SUCCESS: A MODERATION ROLE OF HIGHER EDUCATION}

\begin{abstract}
Studies revealed that college readiness promotes college success and higher education student learning outcomes. This study opted to 1) analyze the total effect and the conditional effect of college readiness on college success by university generations and departments; 2 ) analyze the differences in the probability of college success across departments and university generations; 3 ) describe the quality of university generations in terms of the conditional effects and the probabilities of college success. The study is an ex post facto research. The Ethiopian 1st, 2 nd, and 3rd generation universities; and the National Educational Assessments and Evaluations Agency officers were the population of the study. The total sample size was 551. The Ethiopian General Education School Leaving Certificate Examination Grade Point Average, the Ethiopian Higher Education Entrance Examination score, and the College Cumulative Grade Point Average of the students were sources of the data. Using the Process Procedure for Software Package for Social Sciences, the binomial logistic regression was conducted. Maintaining the highest total conditional effect of college readiness on college success while heightening the probability of college success at a value of college readiness has been interpreted as a trait of the high performing university generation.
\end{abstract}

\section{KEYWORDS}

\section{College readiness, college success, higher education quality}

\section{HOW TO CITE}

Wariyo L., Asgedom A. (2021) 'Promoting Effects of Abilities While Enhancing Probability of College-Success: A Moderation Role of Higher Education', Journal on Efficiency and Responsibility in Education and Science, vol. 14, no. 2, pp. 101-117. http://dx.doi. org/10.7160/eriesj.2021.140204

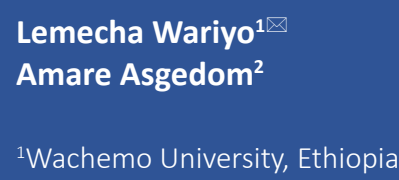

${ }^{2}$ Addis Ababa University, College of Education, Department of Curriculum and Instruction, Ethiopia

lemecha.geleto@aau.edu.et

\section{Article history}

Received

September 11, 2020

Received in revised form

March 15, 2021

Accepted

May 12, 2021

Available on-line

June 30, 2021

\title{
Highlights
}

- College readiness affects college success.

- The conditional effect of college readiness on college success varies by university generations and departments.

- The probability of college success at the value of college readiness varies by university generations and departments.

- Maintaining the effect of college readiness on college success while heightening the probability of college success is a trait of high-performing university generations.

\section{INTRODUCTION}

College-ready students are more prepared for postsecondary education and expectations, as well as for workforce, social, and political responsibilities than less college-ready students (Mokher and Leeds, 2019). One of the strong determinants of college outcomes is the development of pre-college academic skills and readiness (Fina, Dunbar and Welch, 2018; Jackson and Kurlaender, 2014; Olani, 2017). Because of their unpreparedness for college-level learning, many college entering students are assigned to non-credit-bearing remedial education (Leeds and Mokher, 2019; Kallison, 2017; Relles, 2016). For these reasons, the college readiness factor is one of the most important issues ever discussed in educational research. College readiness is a dynamic term that is highly affected by time and space. The definitions may follow the changes in philosophies, aims, and objectives of global education and country-specific education (Klarin, 2016). For instance, the post-COVID 19 definitions of college readiness and success are having another shape. The average definition of college readiness is the maturity level of the students for college-level learning and expectations. Maturity level in a sense may show differences from place to place and from time to time. 
Indicators of college readiness are course-taking, high school Grade Point Average (GPA), college entrance GPA, class rank, and Scholastic Aptitude Tests (SAT). Also, assignment to remediation, degree completion, time to degree, and cumulative college GPA have been discussed as the major indicators of college success (Hsieh, 2019; Davidson, 2015; Tucker and McKnight, 2019; Leeds and Mokher, 2019; Gaertner and McClarty, 2015; Kemple, Segeritz and Stephenson, 2013; Rasinski et.al, 2017; Balfanz and Byrnes, 2019). The current criticisms state that standardized measures of college readiness, such as the SAT and Program for International Student Assessment (PISA) are externally imposed, traditional, and they do not represent the local classroom learning and culture of learners (González Canché, 2019; Kim and Sunderman, 2005). These tests bias for high socio-economic families, and gender (Rattani, 2016; Saygin, 2020). Additionally, scholars state that the number of courses taken may not guarantee college readiness if they are not rigorously mastered (Callahan and Hopkins, 2017; Nagle et al, 2016; Wang, 2017).

On the other hand, college readiness is not fully the function of academic performance (Gray, Mcguinness and Owende, 2016; Savitz-Romer and Rowan-Kenyon, 2020). The non-cognitive factors, such as time management, finance, social integration, satisfaction with the institutional environment, perseverance, conscientiousness, motivation, goal-setting, help-seeking, selfadvocacy, self-efficacy, critical thinking and reasoning, and college knowledge share the largest variance in college success than academic factors (Cho and Serrano, 2020; Tierney and Duncheon, 2015; Fennie et al, 2020). Despite the criticisms on them, utilization of the academic college readiness measures for college admission and placement decisions is very high compared to other measures. Academic preparation is the most determinant of college completion (Means et al, 2016). Also, a recent standards approach to curriculum design and standards-based test development increased the validity and the reliability of academic measures (Lunceford, Sondergeld and Stretavski, 2017; Hughes, 2006). The factors, such as the nature of the curriculum, the content, and the format of these academic measures highly determine academic measures' validity and reliability in measuring college readiness.

The studies and trends around the world took to the forefront the issue of consolidating and heightening the standards and quality of college readiness as one of the mechanisms to improve the quality of higher education (HE) outcomes. The reforms in terms of curriculum development, implementation, and assessment standards are the major academic approaches in building college readiness. Additionally, the more recent approach to HE quality assessment is taking into account these college readiness standards as a baseline in estimating the contributions of higher education institutions (HEIs) to student learning.

Although multiple factors widened the gaps between theory and practice, the Ethiopian Ministry of Education (MOE) (2009) has made reforms in terms of curriculum revisions to maintain the standards through the curriculum, especially in the form of shifting to competency-based curriculum development. The college readiness is realized when the written curriculum is rigorously practiced and integrated with the life world of learners throughout k-12 education. The validity and reliability of assessments also facilitate and monitor the effectiveness of student learning and they are the tools of assuring meritocracy and quality in student learning.

Regarding this, National Educational Assessments and Evaluations Agency (NEAEA) officer was interviewed to study the processes in determining cutting scores for the Ethiopian HE entry, and the test development processes. The interview result showed that college entry cutting score determination for different groups of applicants is dependent on the resource availability and the capacities of the universities. Taking the contextual factors into consideration as a good approach, however, the decision process failed to consider some scientific processes that are followed in different parts of the world. For instance, the yearly continuous studies that relate the cutting scores of the affirmative action groups and their college performances should have been used as additional information to make the decisions.

Also, an interview response from an Ethiopian Higher Education Relevance and Quality Assurance (HERQA) officer revealed that the Ethiopian quality assessment system did not consider the college readiness factors of the students as a covariate in assessing the performances of the HEIs. The current Ethiopian HE quality assessment system gives less attention to the direct assessment of HE learning outcomes (Wariyo, 2020). The research designs that take into account the contribution of college readiness need to guide the decisionmaking process in placement, admission, and HE quality assessment process. Furthermore, a comparative analysis of conditional effects of college readiness on college success at values of universities and fields of studies is important to study how the abilities of students are linked across universities and departments.

Student college readiness levels for college learning and expectation is one of the major factors that affect the student learning outcomes of HEIs. This is reflected in performancedependent funding of HE policies in which the institutions compete to attract high-performing high school students. As an input of HE, the college readiness factor of college entering students is highly confounded with HEIs' performances. For this reason, studies considered the contribution of the college readiness level of college entering students in HE quality assessment of the value-added (Coates, 2009; Cunha and Miller, 2014; Jackson and Kurlaender, 2014; Liu, 2011). Also, numerous studies emphasized direct assessment of HE student learning outcomes (Ďurišová, Kucharčíková and Tokarčíková, 2015; Sønderlund, Hughes and Smith, 2019; Martin and Mahat, 2017; Zlatkin-Troitschanskaia, Pant and Coates, 2016; Xu Solanki and Harlow, 2020). Čechová, Neubauer and Sedlačík (2019) used direct student college entrance data and college study results to assess the relationship between college entry scores and college performance. Similar to previous studies, this study dealt with analyzing the relationship between college readiness and college success measures and did not move further to make explanations on the meanings of this relationship in an applied sense. Also, Otavová and Sýkorová (2016) conducted a comparative analysis of college students' performance across different faculties at the University of 
Prague. For the reason that the faculties have diversities in terms of the student abilities and the nature of disciplines, the highly matched groups within and between departments should be compared. The pre-college and college covariates are needed to be controlled.

In the European context, the assurance of the linkage between college readiness and $\mathrm{HE}$ learning quality of students is maintained through curriculum-based standardization and validation of prior learning (Sava, Borca and Danciu, 2014). Similarly, the curriculum standards-based approach is widely used in the USA to raise the students' college readiness in line with changing college expectations (Bridges, Wyatt-Smith, and Botelho, 2017; Alonzo, Mirriahi and Davison, 2019; Boud, 2017). For the reason that there is still no one-fits-all quality assessment model, the multidimensional standards-based HE quality assessment approaches have been being applied to assess HE quality (Boud, 2017; Tasopoulou and Tsiotras, 2017; Hrnčiar and Madzík, 2015; Noaman et al, 2017).

Generally, the HE quality assessment models vary in assessing different aspects of HE quality: 1) direct assessment and indirect assessment of HE quality; 2) consideration and inconsideration of the college readiness factors of the students; and 3) taking into account the value-added to student learning and income, and country's economy. Although dimensions of indirect HE quality, such as the service quality, resource quality, the management quality, quality in curriculum, and teachinglearning process are the causes for the quality of the HE student learning outcomes, the assessment remains incomplete and vague unless the comprehensive pre-college and college indicators and measures precisely link these dimensions of HE quality to changes in student learning.

For this reason, building a comprehensive model that merges the indirect HE quality assessment indicators with college readiness indicators to assess direct HE learning outcomes is highly important. However, previous studies focused on some aspects of HE quality. This study attempted to link the direct college readiness and success measures of the participants to the diversity of the HE to assess 1) how the college readiness factor affects the college success of the participants, 2) the quality of the institutions in linking the precollege and college aptitudes while raising the probability of college success; and 3 ) the extent to which universities and departments vary in maintaining the effect of students' abilities while heightening the probability of college success at the a value of college readiness level.

\section{MATERIALS AND METHODS Models of decision-making}

This study considered test-based decision-making quality in college readiness and success assessment as a major factor that affects the validity of direct HE quality assessment. For this reason, the researchers attempted to make a review of the major decision-making models in this section. This is to show the role of decision-making science in enhancing efficiency through student learning management and thereby contributing significant indirect contribution to HE quality management.

In the decision-making process, the decision-maker chooses a course of action or inaction in which an outcome can be an expected behavior or not (McFall, 2015). The literature on decision-making discussed three major decision-making models: normative, prescriptive, and descriptive (Elqayam and Evans, 2011; Kowalski, 2008; McFall, 2015).

Normative decision-making depends on logic and reason and emphasizes the rationality of the decision-making process. In order to verify the norm and rationality of the decision-making process, normative decision-making science created a linear mathematical process that empirically relates alternatives and consequences. Therefore, the main objective of normative decision-making is choosing the best alternative or a group of alternatives that end in the highest expected utility. A normative decision-maker deals with or is challenged by 1) his/her background information about the problem, 2) what others do, and 3) by features or states of nature in the decision-making process (McFall, 2015; van der Linden, 1991).

Although the normative decision-making model is the most widely applied one, it faced criticisms because 1) people unpredictably behave and the rationality and the logical formula does not capture the reality of human behavior, 2) normative decision-making theories exclude cognitive characteristics of human beings such as, anxiety, charity, envy, and others, 3) there are so many extraneous variables that highly distort the logical expected relationship between the alternatives and consequences (Elqayam and Evans, 2011; McFall, 2015; Raiffa, 1994). Generally, the normative decision-making model is highly criticized for its low ecological validity.

The weaknesses of classical normative models caused the birth of bounded rationality in the second half of $20^{\text {th }} \mathrm{C}$ (McFall, 2015; March, 1978; Wang, 1996). Let's elaborate on the difference between the normative model's expected utility assumption and the bounded rationality theory of the descriptive model. These studies stated that the normative model conducts an endless and exhaustive search for an alternative or a group of alternatives that ends in a maximum expected utility. However, the supporters of bounded rationality stated that this is fruitless and its benefit is low. Also, classical models depend on logic and norm rather than criteria. These proponents of bounded rationality, however, argue that norms and logic do not bring about satisfactory ends, but the criteria do. For this reason, they conduct a sequential search for a satisfactory criterion or standard that brings about satisfaction. In this study's context, we can raise examples. The contemporary college readiness policymakers tend to favor the descriptive approach; they work on selecting and incorporating the best competency-based standards in the curriculum and teaching-learning process before trusting the quantitative college readiness measures through sole predictions of college success.

Baron (2004) stated that, naturally, most of the problems in the world are more descriptive rather than normative; the decisions on them need descriptive procedure than normative procedure. He also stated that descriptive models deal with both actual behavior and reflective judgment. The descriptive decisionmaking model emphasizes heuristics and ethics in the contexts of the decision-making process rather than the algorism and the norm. Although the bounded rationality surpasses the expected utility model in practicality and importance across 
disciplines, the expected utility models are better in precision and parsimony or simplicity (Mcfall, 2015).

On the other hand, Raiffa (1994) and Baron (2004) pointed out that the prescriptive model especially considers the cognitive characteristics of the individuals. Raiffa argued that normative models should modify themselves in a more applicable manner for human behavior. Baron (2004) also asserted that prescriptive models provide the applicable decision-making procedure for individuals integrating the strong sides of normative and descriptive models. These studies describe the prescriptive model as a hybrid of normative and descriptive decision-making models. For instance, the behavioral model highly emphasizes describing behavior as related to consequences and uses mathematical linear procedures. For its descriptive approach towards a behavior (Mcfall, 2015) and, for the fact that it applies the principle of bounded rationality (Kowalski, 2008) in the decision-making process, it resembles the descriptive decision-making model while, on the other hand, for its use of mathematical linear procedure (Kowalski, 2008), it resembles the classical decision-making model.

Concerned with the dispersed roles in the body of decisionmaking models, McFall (2015) stated that the previous decision-making models produced proliferative rather than ameliorative processes for decision-making science, and he argued for the development of a metatheory that integrates the merits of all decision-making models for practice. Also, recent studies by Arnold (2018) and Turner and Angulo (2018) integrated classical and contemporary decision-making models and offered a heuristic for analyzing both internal and external pressures in HE. Also, the mechanisms by which schools and HEIs store and use data for decision-making research help them to make rational and effective decision-making in the selection, admission, and placement (Al-Twijri and Noamanb, 2015; Martín-García, Martínez-Abad and Reyes-González, 2019). In general, the contemporary decision-making models in selection and placement take a pragmatic approach.

\section{Theoretical framework}

This study considered the role of test-based decision-making as one of the determinants of the quality of the inputs and outcomes of HE. Test-based prescriptive decision-making typology in HE is based on the use of flowcharts to define various types of decision-making in education. In each decision problem, three common elements are identified: (i) the test that provides the information is based on, (ii) the treatment at which the decision is made, and (iii) the criterion by which the success of the treatment is measured (van der Linden, 1991; van der Linden, 1996). Ben-Shakhar, Kiderman and Beller (1996) also used a threshold utility model to assess the utility of using the SAT, in addition to other tests, for selecting applicants for liberal arts programs. Sawyer (1996) studied the utility functions of placement tests for standard and remedial course placement.

Sawyer elaborated the application of Bayesian theory in testbased decision making as follows: A placement committee determines a particular cutting score (d) from a set $D$ of possible decisions. Then, after the student is admitted to a course, a particular outcome $\theta$ (e.g., grade in a course) occurs, from a set of possible outcomes $\theta$ (e.g., a set of possible chances of achieving in a course). A Bayesian utility function $u(d, \theta)$ assigns a value to the accuracy and desirability of the decision of the placement committees' cutting score when the outcome is the course grade $\theta$. In the Bayesian decision theory model, this information is described by a subjective probability distribution on $\theta$; the $\theta$ quantifies the placement committees' beliefs about the probable values of $\theta$ assuming that both prior beliefs and any relevant data were previously collected. The Bayesian optimal model is to choose the decision $\mathrm{d}$ that approximates or maximizes the expected value of $u(d, \theta)$ with respect to the subjective probability distribution on $\theta$.

In the educational context, these models are used to predict the utility functions of the tests for selection, admission, and placement purposes. What makes these models relevant in this study is that they relate college readiness and success measures. These models emphasized the decisions on tests and their consequences, and they have not been applied for modeling HE quality assessment. However, this study adopted the decision theory's assumption for HE quality assessment taking into account the role of moderators and covariates. The idea is that the validity of the decision on the college readiness measure significantly affects the outcomes of students' college learning. The effect of the college readiness measure on college success is also affected by the moderators. Therefore, this study hypothesizes that, at a valid measure of college readiness, and at a better role of moderators, a higher conditional effect and probability of college success is expected.

\section{Conceptual framework}

In this study, the independent variable, the Ethiopian Higher Education Entrance Examination (EHEEE) score, and the covariate, the Ethiopian General Education School Leaving Certificate Examination (EGESLCE) GPA were the measures of college readiness. The treatment groups, i.e., the University Generations (UGs) and departments, were used as the moderators between college readiness and college success. Also, it is assumed that placement of the students to different treatment groups depending on their EHEEE score is in the assumption that the EHEEE score helped the individuals to be assigned to suitable areas for them; in other words, the treatment groups are assumed to promote the success of the individuals, and the result of success level of the individuals would be revealed through the criterion College Cumulative Grade Point Average (CCGPA).

Although the assumption of the decision theory is used as a cornerstone in this study, the design of this study is built on the quasi-experimental approach. Unlike former decision models, this study gives a stronger emphasis on the role of moderators. Also, it attempted to control for precollege covariates of college readiness measure. For this reason, this study took a different statistical design from that is stated by Bayesian statistics although it adopted the assumption of decision theory as a cornerstone. 


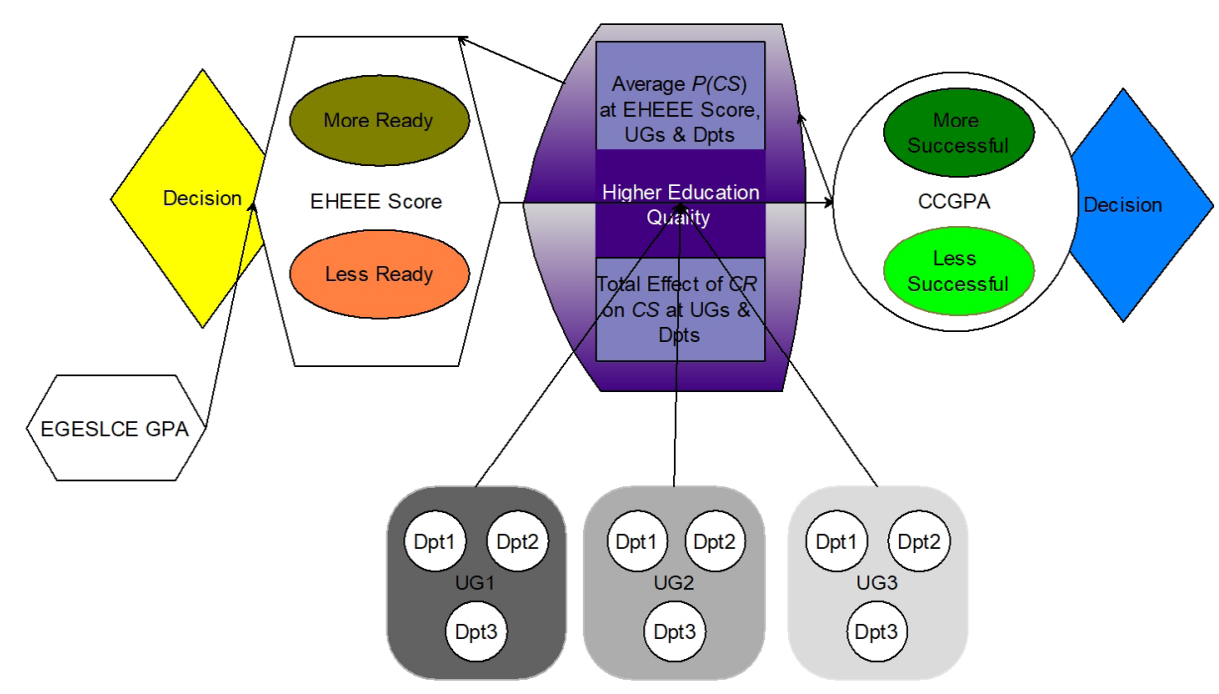

Note: $P(C S)=$ Probability of College Success; $C R=$ College Readiness

$D p t=$ department, UG, EHEEE Score, CCGPA, and EGESLCE GPA are previously defined.

Figure 1: Conceptual framework

\section{Operational Definitions}

In this study, the college readiness is defined as the academic preparation level of the participants for HE as measured by their EHEEE scores. The College Success of the participants is also defined as the college academic performance of the participants as measured by their College Cumulative Grade Point Average (CCGPA). The $U G$ is the coinage given for a group of Ethiopian universities which have approximately the same time of establishment. The department variable in this study refers to a field of study that participants joined after college entry. Also, an aspect of HE quality was measured in this study taking into account the extent that UGs maintain the effect of student aptitudes while they enhance the probability of college success.

\section{Objectives}

The major objectives of this study were to 1) analyze the total effect and the conditional effect of college readiness on college success at the values of UGs and departments; 2) analyze the differences in the probability of college success across departments and UGs at a value of the college readiness measure, and 3) describe the quality of UGs depending on the sum of the total conditional effects and the probabilities of college success.

\section{Research methodology}

\section{Hypotheses}

The major null and alternative hypotheses of this study were spelled out as follows:

1. H0a: The effect of college readiness on college success is not significant.

2. H1a: There is a significant effect of college readiness on college success.

3. HOb: The conditional effect of college readiness on college success does not significantly differ by UGs and departments.
4. H1b: The conditional effect of college readiness on college success significantly differs by UGs and departments.

5. H0c: The probability of college success at a value of college readiness does not significantly vary by UGs and departments.

6. H1c: The probability of college success at a value of college readiness significantly varies by UGs and departments.

7. H0d: A UG with the highest total conditional effect of college readiness on college success has no highest average probability of college success

8. H1d: A UG with the highest total conditional effect of college readiness on college success has also the highest average probability of college success.

\section{The research paradigm}

The research paradigm is defined as a broad philosophical approach to understanding and researching a phenomenon (Cohen, Manion and Morrison, 2018). The positivist approach makes a quantitative theoretical explanation of a problem depending on what is observed (Hughes and Sharrock, 1997). Post-positivists argue that the positivists' search for the absolute truth of knowledge only through observable data cannot be achieved, particularly, when studying the behavior and actions of humans (Creswell, 2014; Cohen, Manion and Morrison 2018). For this reason, post-positivists updated the assumption of positivists and took a deeper approach to understand a phenomenon; they use additional methods to get adequate information about a phenomenon in addition to observable data.

In the process of understanding the relationship between college readiness, college success, UGs, and departments, this study took a post-positivist stance. After making a quantitative description of the nature of the relationship between these variables, some possible underlying contextual factors that can modify these relationships have been discussed. For this reason, this study moves beyond the deductive test-based 
decision theory's assumption in understanding the nature of the relationship between these variables.

\section{Explanatory correlational research design}

Explanatory correlational research design gives explanations on how one variable affects another variable by using more advanced statistical tests, such as regression and Analysis of Variance (Ary et al, 2010; Edmonds and Kennedy, 2017). In this study, how college readiness explained college success through UGs and departments was studied. A type of explanatory correlational research design, i.e., causalcomparative ex post facto design, was a research design of this study. In this design, the groups were those more collegeready and less college-ready participants as they have been grouped depending on the manipulation of the independent variable (i.e., EHEEE). The dependent variable is college success as measured by the CCGPA. The design also included moderating variables (UGs and Departments), and a covariate (i.e., EGESLCE GPA).

\section{Sampling}

It is stated in the theoretical framework of the study that students are placed in various departments (treatments) depending on the college entrance test results. It is assumed that the assignment of the groups to different categories and the manipulation of the variables to observe the effects had already been accomplished by other bodies (MOE and Universities) other than the researcher. For this reason, this study is an ex post facto experimental research in which already matched groups have been selected using a combination of probability and non-probability sampling design. For the reason that universities have significant diversities, the best approach to take a representative group was careful matching, inclusion, and exclusion of the already formed groups.

To this end, the sampling process followed this procedure: 1) the total 33 universities from the three UGs were listed; 2) depending on their similarities in terms of the faculties they consisted of, the total 30 UGs $\left(91^{\text {st }}\right.$ generation, $112^{\text {nd }}$ generation, and $103^{\text {rd }}$ generation) were included in the study. The rest three universities, such as Ethiopian Defense University, Civil Service University, and Adama Science and Technology University were excluded from the study because they show a significant difference from others; 3$)$ The stratified sampling formula ${ }^{1}, n_{k}=(n / N) N_{k}$ was used to calculate the number of universities should be selected from every three groups of universities; 4) After sample size determination and calculation, the total three UGs (i.e., one 1 st, one $2 \mathrm{nd}$, and one 3rd generation universities) were randomly selected from each of the three groups; 5) These three universities were compared depending on the faculties they consisted of, and the faculties that were not found in all three universities were excluded from the sample; 6) Three faculties (i.e., Business and Economics, Social Sciences and Humanities, and Natural and Computational Sciences) were randomly selected from the faculties that represent all three universities. In this case, for the reason that the three universities have the same type and number of faculties, the number of faculties that should be selected from each university was not calculated; 7) the departments in all three selected faculties were also matched. Then, departments that were not found in all three faculties were also excluded from the sample; 8) Three departments (i.e., accounting, psychology, and mathematics) were randomly selected from the departments that represent all three faculties; 9) all students in these three departments were included in the study. The $202($ Male $=128$, Female $=74)$ participants from first generation; the $168($ Male $=91$, Female $=77)$ participants from second generation; the $181($ Male $=107$, Female $=74)$ participants from the third-generation university were included in the study. Due to time and financial constraints, only three departments were selected for the study. When all participants are added together, the total sample is 551. Also, two key informants (i.e., one from NEAEA and one from HERQA) were purposively selected for interview using the purposive sampling of non-probability sampling design.

\section{Interviews}

The primary data for this study was the NEAEA and HERQA officers' interview responses. These data were collected through an unstructured interview that was guided by two general interview questionnaire items: 1) How HE quality assessment relates to the college readiness and success measures of students and, 2) What are the procedures of HE entry cutting scores? In this case, the HEQRA officer responded only to the first interview questionnaire item; the second questionnaire item does not refer to him.

\section{Data collection procedure for the interview data}

Before the pilot visit, a formal letter was received from the department of Curriculum and Instruction at Addis Ababa University. During the pilot visit, appointments and schedules were arranged to contact the participants at NEAEA and HERQA. Depending on the appointments, the NEAEA and HERQA participants were interviewed. During the interview, the major responses for the interview were recorded into a notebook.

\section{Academic achievement data}

The academic achievement data for this study were three types: 1) The EGESLCE GPA; 2) the EHEEE score, and 3) the CCGPA. The EGESLCE is a grade 10 nationally prepared certificate examination. This examination recognizes the eligibility for the entry of the Ethiopian Preparatory School for HE. Students who are not eligible for preparatory school enter technical vocational education and training institutions and teachers' college. The EHEEE is a nationally prepared examination for the national assessment of preparation for $\mathrm{HE}$ entry. The third document data were the CCGPA of the 2011 Ethiopian Calendar (E.C.)/2018/2019 G.C. graduates.

The EGESLCE tests achievements in 10 subjects, such as Mathematics, English, Geography, History, Biology, Chemistry, Physics, General Academic Aptitude, Civics, and Ethical Education and one subject test that belongs to a local or regional language of the students (NEAEA, 2019; Trines, 2018).

\footnotetext{
$\overline{1} n_{k}=$ the sample size for $k_{\mathrm{th}}$ strata; $N_{k}=$ the total population of $k_{\mathrm{th}}$ strata; $N=$ the total population size; $n=$ total sample size
} 
Grading scales of EGESLCE follow A-F norm-referenced scale. A cumulative GPA out of 4.00 is calculated for each of the exam takers. The MOE decides on the minimum cutting score of EGESLCE that makes it eligible for preparatory for HE school.

Grades 11 and 12 are known as the preparatory for HE grades in Ethiopia. Depending on their EGESLCEGPA, students choose either a natural science stream or a social science stream. These streams provide common core courses, such as English, mathematics, physical education, civics, information communications technology, and an elective language (Amharic or local languages). The common core curriculum makes up $60 \%$ of the study load. The courses, such as Biology, Chemistry, Physics, and Technical Drawing are taught in the natural science track whereas geography, history, economics, and business are covered by the social science track (NEAEA, 2019; Education in Ethiopia, 2019).

Students sit for the EHEEE at the end of grade 12. The EHEEE for the social science stream tests achievement in seven subjects, such as mathematics, English, civics, general academic aptitude, history, geography, and economics. Also, the EHEEE for the natural science stream tests the achievement in the seven courses, such as mathematics, English, civics, general academic aptitude, biology, chemistry, and physics.

The EHEEE grading follows a criterion-referenced scoring system; achievements in the subjects are graded on a numerical 0-100 point scale with a total possible score of 700 in the seven test subjects combined. The performance of students in each seven test subjects is converted to 100, and all of them are added and graded out of the total possible score of 700. (NEAEA, 2019; Education in Ethiopia, 2019).

The general grading scales and credit systems that are used in the Ethiopian HEIs share similarities with those that are used in U.S. universities; however, some Ethiopian universities have recently started using the European Credit Transfer and Accumulation System (ECTS). One credit unit is defined as one contact hour per week that is taken over a span of 16 weeks in most of the public
Ethiopian universities including the sample universities for this study. The common minimum credit requirement in most of the four-year bachelor's programs is 128 to 136 credits (i.e., 16 or 17 credits or 30 ECTS per semester). Also, a three-year degree can be completed with a minimum of 102 to 108 credits (i.e., 180 ECTS) (NEAEA, 2019; Education in Ethiopia, 2019). All sample departments that were included in this study graduate with threeyear degrees. The largest number of Ethiopian universities uses a standard A-F scale. However, some institutions use a simplified version without the "+" and "-" designations. To graduate from bachelor's programs, a minimum cumulative GPA of 2.0 (C) is required (NEAEA 2019; Education in Ethiopia, 2019).

\section{Data collection procedure for academic achievement data}

The document data collection was accomplished in the following procedure: 1) the principal researcher visited the academic vice president offices of the selected universities and received permission to conduct the research;2) the academic vice presidents sent letters to the registrars of the universities; 3 ) the heads of registrars formally instructed technical registrar record officers to cooperate on the collection of EGESLCE GPA, EHEEE score, and CCGPA; 4) the researchers made arrangements and appointments with the registrar record officers to collect data. Those data that had not been archived online on the computer were collected from the records. The data collectors who collected the data from the records were funded. Those registrars, whose data were available online, sent the organized data to the researchers via email. Others printed the data and gave it to the researcher.

Also, the documents, such as journal articles, dissertations and theses, books, and conference reports were collected in hardcopy in local libraries and in softcopy from online accredited sources. Especially, those journals subscribed by AAU, such as Science Direct sources, Sage Journals, and Emeralds were the major literature sources for this study.

\begin{tabular}{|c|c|c|c|c|c|c|c|c|c|c|}
\hline \multirow[t]{2}{*}{ UG } & \multirow[t]{2}{*}{ Department } & \multicolumn{3}{|c|}{ EHEEE Score } & \multicolumn{3}{|c|}{ EGESLCE GPA } & \multicolumn{3}{|c|}{ CCGPA } \\
\hline & & M & SD & $\mathbf{N}$ & $\mathbf{M}$ & SD & $\mathbf{N}$ & M & SD & $\mathbf{N}$ \\
\hline \multirow{4}{*}{1} & Accounting & 443.11 & 58.92 & 138 & 3.10 & .44 & 138 & 2.89 & .47 & 138 \\
\hline & Psychology & 351.58 & 24.58 & 40 & 2.77 & .26 & 40 & 2.75 & .52 & 40 \\
\hline & Maths & 393.83 & 25.66 & 24 & 3.01 & .37 & 24 & 2.99 & .49 & 24 \\
\hline & Total & 419.13 & 62.76 & 202 & 3.03 & .42 & 202 & 2.88 & .49 & 202 \\
\hline \multirow{4}{*}{2} & Accounting & 399.80 & 20.72 & 115 & 2.95 & .41 & 115 & 2.84 & .47 & 115 \\
\hline & Psychology & 342.39 & 16.05 & 38 & 2.78 & .43 & 38 & 2.74 & .50 & 38 \\
\hline & Maths & 361.27 & 16.96 & 15 & 2.90 & .23 & 15 & 2.74 & .40 & 15 \\
\hline & Total & 383.38 & 31.40 & 168 & 2.91 & .41 & 168 & 2.81 & .47 & 168 \\
\hline \multirow{4}{*}{3} & Accounting & 408.59 & 21.34 & 135 & 3.03 & .31 & 135 & 2.88 & .47 & 135 \\
\hline & Psychology & 352.75 & 9.11 & 24 & 2.72 & .23 & 24 & 2.92 & .64 & 24 \\
\hline & Maths & 363.32 & 15.91 & 22 & 2.81 & .24 & 22 & 2.96 & .57 & 22 \\
\hline & Total & 395.69 & 29.63 & 181 & 2.96 & .32 & 181 & 2.90 & .50 & 181 \\
\hline \multirow{4}{*}{ Total } & Accounting & 418.26 & 43.21 & 388 & 3.03 & .39 & 388 & 2.87 & .47 & 388 \\
\hline & Psychology & 348.43 & 19.20 & 102 & 2.76 & .33 & 102 & 2.79 & .55 & 102 \\
\hline & Maths & 374.82 & 25.44 & 61 & 2.93 & .31 & 61 & 2.92 & .50 & 61 \\
\hline & Total & 400.53 & 47.44 & 551 & 2.98 & .39 & 551 & 2.86 & .49 & 551 \\
\hline
\end{tabular}

Note: $M=$ Mean; $S D=$ Standard Deviation; UG = University Generation; EHEEE = Ethiopian Higher Education Entrance Examination; EGESLCE = Ethiopian General Education School Leaving Certificate Examination; CCGPA = College Cumulative Grade Point Average

Table 1: Descriptive statistics for document score data 


\section{Data analysis method}

The Process Procedure for SPSS was installed on the SPSS software version 24 and used for the analysis. In this analysis, the effect of college readiness on college success; the conditional effects of college readiness on college success at the values of the UGs and departments; and the probabilities of college success at the values of college readiness level, UGs, and departments were analyzed. Using the binomial logistic regression analysis as the statistical method, the EHEEE score was used as a continuous predictor variable while the UG (i.e., coded as UG1, UG2, and UG3) and department (i.e., coded as Dpt1, Dpt2, and Dpt3) were used as categorical moderators. Also, the EGESLCE GPA was used as a continuous covariate; the CCGPA less than 2.75 was coded as 'less successful', and the CCGPA greater than or equal to 2.75 was coded as 'more successful' was used as a binary dependent variable.

The assumption of linearity in logistic regression assumes that there should be a linear relationship between quantitative predictors and the logit of the outcome variable. This assumption was tested by analyzing the interaction term between the predictor (EHEEE score) and its log transformation, and found that the interaction was not statistically significant $\left({ }^{1} B=.03\right.$, $\left.{ }^{2} s e=.03, p>.05\right)$. The interaction term between EGESLCE and its $\log$ transformation was also not significant $(B=-6.04$. $s e=3.88, p>.05)($ See Appendix 2). For this reason, the assumption of linearity was met in this study.

According to Menard (1995), tolerance values less than 0.1 show multicollinearity in the data for the regression analysis. For the reason that the logistic regression does not have the multicollinearity analysis option, testing multicollinearity through linear regression for the logistic regression data is recommended (Field, 2018). In this study, the multicollinearity assumption was checked by running the multicollinearity test using linear regression analysis in SPSS. All tolerance values for the independent variables were greater than 0.1 and all the VIF values were less than 10 (see Appendix 3), and this shows that there were no high correlations between independent variables.

\section{Sample size determination}

To check the adequacy of the sample for binomial logistic regression test, a priori type of power analysis was used in G-power software version 3.1.9.6 (2020). Using effect size input mode of probabilities and the Hsieh, Bloch and Larsen (1998) procedure in G-power, and when the following input parameters were used: Tails $=2 ; \operatorname{pr}(y=1)(x=1) \mathrm{H} 1=.6$; $\operatorname{pr}(y=1)(x=1) \mathrm{Ho}=.05$; alpha error probability = .05; power(1-beta error probability) $=.95 ; R^{2}$ other than $x=0$; $x$ distribution $=$ normal; $X$ population mean $=0 ; X$ standard population deviation $=1$, the appropriate sample size was 317 . Also, the critical $z=1.96$ and the actual power was also.95.
Therefore, the total sample size $(n=551)$ of this study is more than adequate for binomial logistic regression.

\section{Ethical considerations of the study}

Before the data collection, the universities' Academic Vice Presidents were contacted; and presidents sent the formal letters to the registrar officers. Then, assurance of the confidentiality for data was clearly described to all concerned groups, and the data were collected after the researchers have received the consent from the participants. In the research report, the names of the universities were left anonymous for purpose of ethical considerations.

\section{RESULTS}

The study was aimed at testing these hypotheses: 1) H1a: There is a significant effect of college readiness on college success; 2) H1b: The conditional effect of college readiness on college success significantly differs by UGs and departments; 3) H1c: The probability of college success at a value of college readiness significantly varies by UGs and departments; 4) H1d: A UG with the highest total conditional effect of college readiness on college success has also the highest average probability of college success.

\section{The effect of college readiness on college success}

It is a generally accepted meritocratic assumption in any education system that college readiness significantly affects college success. In other words, well-ready students will successfully complete their college studies than less college-ready students. However, the degree of preserving this meritocratic principle in education for quality is highly affected by so many institutional and non-institutional moderating and confounding factors. Controlling for some covariates and moderating factors, this study tested the first hypothesis that 'H1a: There is a significant effect of college readiness on college success.' Using the EHEEE score as a continuous predictor variable; the EGESLCE GPA as a continuous covariate, UG and department as moderators, and the CCGPA as a binary criterion variable, the process procedure for SPSS was used to analyze the effect of college readiness on college success at the values of UGs and departments.

As can be seen from Table 2, when the college readiness measure (EHEEE score) is used as a predictor, and the EGESLCE GPA used as a covariate, the model significantly predicted college success (i.e. as measured by CCGPA), Nagelkerke $R^{2}=.26$, $p<.001$. Also, the EHEEE score significantly predicted college success, $B=.02, S e=.00, C I=.01-.03$. Therefore, this study fails to reject the hypothesis, 'H1a: There is a significant effect of college readiness on college success.' 


\begin{tabular}{lrrr}
\multicolumn{1}{c}{ Coefficients } & \multicolumn{1}{c}{$\boldsymbol{B}(\mathrm{se})$} & \multicolumn{1}{c}{ LLCI } & \multicolumn{1}{c}{ ULCI } \\
\hline Constant & $-10.79^{* * *(1.65)}$ & -14.01 & \multicolumn{1}{c}{-7.56} \\
\hline EHEEE Score & $.02^{* * *}(.00)$ & .01 & .03 \\
\hline W1 & $-.04(3.10)$ & -6.03 & 6.12 \\
\hline W2 & $2.40(2.92)$ & -3.32 & 8.12 \\
\hline EHEEE Score $x$ W1 & $.00(.01)$ & -.01 & .02 \\
\hline EHEEE Score $x$ W2 & $.00(.01)$ & -.02 & .01 \\
\hline Z1 & $-18.21^{*}(6.64)$ & -31.23 & -5.20 \\
\hline Z2 & $-5.78(6.60)$ & -18.72 & 7.17 \\
\hline EHEEE Score $x$ Z1 & $.06 * * *(.02)$ & .02 & .09 \\
\hline EHEEE Score $x$ Z2 & $.02(.02)$ & -.02 & .05 \\
\hline EGESLCE GPA & $.94 *(.35)$ & .26 & 1.61
\end{tabular}

Note: ${ }^{*} p<.05 ;{ }^{* *} p<.01 ;{ }^{* *} p<.001 ;$ ModelLL = 116.95; $d f=10 ; p<.001 ;$ Nagelkerke $R^{2}=.26 ;$ W1 = UG2; W2 = UG3; Z1 = Department 2; $\mathrm{Z2}=$ Department 3

Table 2: The effect of college readiness on college success $(N=551)$

\section{The conditional effect of college readiness on college success}

The extent to which the effect of college readiness on college success is promoted may not be similar across UGs and departments. This study defined this quality of UGs as quality in linking student aptitudes. The conditional effect of college readiness on college success at the values of UGs and departments (see table 3) was used to test the second hypothesis, 'H1b: The conditional effect of college readiness on college success significantly differs by UGs and departments.'

\begin{tabular}{|c|c|c|c|c|c|c|c|}
\hline UG & Dpt & Effect(se) & $Z$ & LLCI & ULCI & Effect scores & Total effects \\
\hline 1 & 1 & $.02 * * *(.00)$ & 4.32 & .01 & .03 & 3 & \multirow{3}{*}{6} \\
\hline 1 & 2 & $.07 * * *(.02)$ & 3.92 & .04 & .11 & 3 & \\
\hline 1 & 3 & $.04(.02)$ & 2.10 & .00 & .07 & 0 & \\
\hline 2 & 1 & $.02 *(.01)$ & 2.55 & .00 & .04 & 1 & \multirow{3}{*}{5} \\
\hline 2 & 2 & $.08 * * *(.02)$ & 4.22 & .04 & .11 & 3 & \\
\hline 2 & 3 & $.04 *(.02)$ & 2.26 & .01 & .07 & 1 & \\
\hline 3 & 1 & $.01(.01)$ & 1.87 & .03 & .11 & 0 & \multirow{3}{*}{3} \\
\hline 3 & 2 & $.07 * * *(.02)$ & 3.51 & .00 & .03 & 3 & \\
\hline 3 & 3 & $.03(.02)$ & 1.91 & -.002 & .07 & 0 & \\
\hline
\end{tabular}

Note: ${ }^{*} p<.05 ;{ }^{* *} p<.01 ;{ }^{* * *} p<.001 ;{ }^{* * *}=3 ;{ }^{* *}=2 ;{ }^{*}=1$

The effect scores $\left({ }^{* * *}=3 ;{ }^{* *}=2 ;{ }^{*}=1\right)$ are the measurements given to the significance level of conditional effects to produce simple method to compare the differences across institutions. For example, the effect score for $p<.05$ is less than the effect score for the $p<.01$.

Table 3: The conditional effect of college readiness on college success at the values of the moderators

The conditional effect of college readiness on college success at the values of the first two departments in the UG1 is statistically significant, $p<.001$ in both cases (see Table 3 ). However, the conditional effect is not statistically significant for department three, $p>.05$. The total conditional effect at UG1 is the highest compared to others, total effect $=6$ (Table 3); Mean EHEEE score $=419.13$ (Table 1).

The conditional effect of college readiness on college success is also found to be statistically significant at the values of three departments in UG2, $p<.05, p<.001$, and $p<.05$ respectively. However, the total conditional effect is equal to 5 (table 3 ); Mean EHEEE score $=383.38$ (Table 1$)$.
In UG3, the conditional effect is statistically significant only at the value of department two, $p<.001$. The conditional effect is not significant at the values of the rest two departments, $p>.05$. The total conditional effect is the lowest in the UG3, total conditional effect $=3$; Mean EHEEE score $=395.69$. The total conditional effects for UG1 and UG2 show similarity (i.e. 6 and 5). Both of the UGs moderated the effect of college readiness on college success in a similar manner. Generally, this study failed to reject the hypothesis, 'H1b: The conditional effect of college readiness on college success significantly differs by UGs and departments.' 


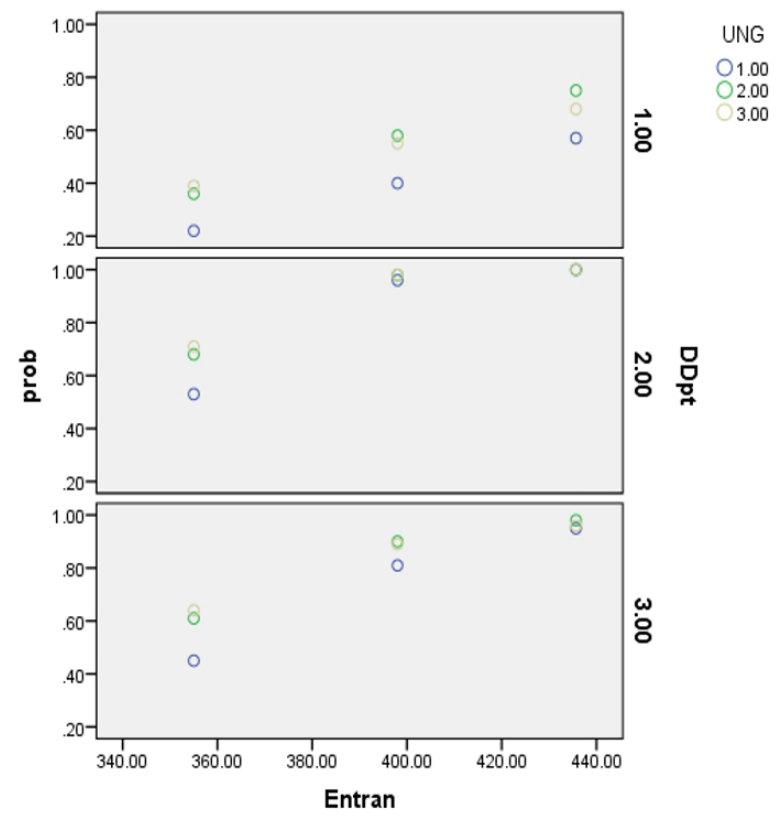

Note: $U N G=$ University Generation; $D D p t=$ Department Entran $=$ EHEEE score $;$ prob $=$ Probability of college success

Figure 2: The probability of college success at the values of college readiness, UG, and department

\section{The probability of college success at a value of college readiness, UGs, and departments}

When the measurement of college success is seen in a comparative view, many factors can be considered. The two factors that can be considered are the students' college readiness level and the institutional diversities. The probability that the UGs heighten college success is gauged at the values of college readiness. If the probability of college success for a group of students with a higher college readiness level is found to be lower compared to a group of students with lower college readiness, the measurement of college success for employment may go wrong. To analyze this issue, this study tested the hypothesis, 'H1c: The probability of college success at a value of college readiness significantly varies by UGs and departments.'

In this section, the probability of achieving more than or equal to 2.75 in CCGPA at a value of EHEEE score was studied. Appendix 1 and figure 2 displayed the probability of college success (i.e., achieving greater than or equal to CCGPA of 2.75) at a value of an EHEEE score across UGs and departments when the contribution of EGESLCE GPA is taken into account. In other words, it answers the question, 'when the contribution of EGESLCE GPA is taken into account, what is the probability of achieving more than or equal to $\mathrm{CCGPA}=2.75$ at a value of EHEEE score for somebody who joins one of these three UGs and departments?'

The probability of college success is lowest for UG1, total sum $p$ level $^{3}=14$; whereas it is 20 and 19 for UG2 and UG3 respectively (see Appendix 1 and figure 2). This finding indicates that those students who join UG2 and UG3 with a value of EHEEE score tend to graduate with high CCGPAs compared to those students who join UG1. It is clearly shown in figure 2 that students who joined UG1, especially those students with lower EHEEE score, achieved lower CCGPA

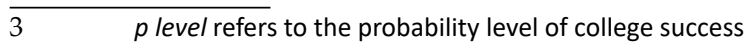

than their peers in other UGs with the same EHEEE score. Therefore, this study failed to reject the hypothesis, 'H1c: The probability of college success at a value of college readiness significantly varies by UGs and departments.'

\section{College readiness, college success, and HE quality}

Linking students' aptitudes through promoting the effect of college readiness on college success is not sufficient if the students cannot be competent in the job market according to their abilities. In other words, the higher linkage of abilities needs to imply higher college success. To deal with this issue, this study tested the hypothesis, 'H1d: A UG with the highest total conditional effect of college readiness on college success has also the highest average probability of college success.'

Depending on the analysis results, the quality of UGs was interpreted from three perspectives: 1) Those UGs that promote the effect of college readiness on college success are more successful in linking the aptitudes of students in education; 2) Naturally, heightening the probability of college success at a value of college readiness is what is expected from any HEI; and 3) Maintaining the highest conditional effect of college readiness on college success while heightening the probability of college success at values of college readiness is a trait of high performing UGs. Therefore, these perspectives have to be promoted simultaneously in order to enhance the performance. Table 4 shows that UG1 is the best in linking student abilities compared with others as it registered the highest total conditional effect (Total effect for UG1 =6). However, its power in enhancing the probability of college success at a value of college readiness is lower than UG2 (Average probability of college success for UG1 $=4.67$; for $\mathrm{UG} 2=6.67)$. On the other hand, UG1 and UG2 have similar performance (e.g., performance $=10.67$ for UG1, and 11.67 for 
UG2) in promoting the effect of college readiness on college success while increasing the probability of achieving high in CCGPA at a value of college readiness. Relatively, UG2 has the highest performance compared to the others. Therefore, the alternative hypothesis, 'H1d: A UG with the highest total conditional effect of college readiness on college success has also the highest average probability of college success,' is rejected in this study. Universities can link the student aptitudes by maintaining the effect of college readiness on college success but they may still fail to heighten the probability of college success at a value of college readiness if their students show low average performance in their cumulative graduation GPAs compared to the graduates from peer UGs.

\begin{tabular}{|c|c|c|c|c|}
\hline UG & Department & Total conditional Effect & Average Probability of college success & Performance \\
\hline \multirow{3}{*}{1} & 1 & \multirow{3}{*}{6} & \multirow{3}{*}{4.67} & \multirow{3}{*}{10.67} \\
\hline & 2 & & & \\
\hline & 3 & & & \\
\hline \multirow{3}{*}{2} & 1 & \multirow{3}{*}{5} & \multirow{3}{*}{6.67} & \multirow{3}{*}{11.67} \\
\hline & 2 & & & \\
\hline & 3 & & & \\
\hline \multirow{3}{*}{3} & 1 & \multirow{3}{*}{3} & \multirow{3}{*}{6.33} & \multirow{3}{*}{9.33} \\
\hline & 2 & & & \\
\hline & 3 & & & \\
\hline
\end{tabular}

Note: Average Prob. of College success $=$ Sum p level Total for a UG /3; Performance $=$ Total Conditional Effect + Average Probability of College success

Table 4: Performance: Total effects and average probability of college success

According to the current practice in Ethiopia, the CCGPA equals to or greater than 2.75 is the most acceptable in the job market. For this reason, the probability of being recruited (i.e. 4.67 for UG1) in the job market is lower than those who graduated from UG2 and UG3 even though UG1 graduates were wellprepared for college and their ability significantly affected their CCGPA. Most probably, this happens when the UGs focus on a conservative approach in guiding student learning and assessment regardless of utilizing supportive approaches to different groups of students to raise their CCGPA.

\section{DISCUSSION}

Even though academic measures of college readiness, such as SAT scores, High School CPAs, class ranks, and others have faced criticisms in terms of their depth in assessing student readiness, their fairness and freedom from bias, and the low variance they share in explaining college readiness (Niu and Tienda, 2010; Atkinson and Geiser, 2009; Kim and Sunderman, 2005; Lehman, 1999; Rattani, 2016), they are still highly utilized and leading measures of college success. On the other hand, college outcomes are also measured through the number of credits earned in college, CCGPAs, alumni income levels, retention, assignment to remediation, and degree completion. Similar to academic college readiness measures, academic college success measures, e.g., CCGPAs, dominate other college success measures in selection for employment. Especially, the academic college readiness measure (e.g. EHEEE) plays a dominant role in HE entry decisions while the college CCGPA also shares the largest percentage in the decision process of screening the graduates for employment in Ethiopia.

Consistent with the result of this study, previous studies by Allensworth and Clark (2020), Galla et.al (2019), and Shewach et.al (2017) revealed that academic college readiness measures significantly predict college success. Beyond predicting college success from college readiness using these measures, the recent applied studies used the academic college readiness measures as covariates while they used college cumulative GPAs as measures of college outcomes in HE quality assessment studies (Coates, 2009; Liu, 2011; Jackson and Kurlaender, 2014). Also, the value-added HE quality assessment models emphasize direct measurement of student learning outcomes (Shavelson et al, 2016; Brown, McNamara and O'Hara, 2016; Sønderlund et al, 2019).

Although the previous studies used the college readiness and success measures for modeling and estimating the HE quality of the value-added, they did not compare conditional effects of college readiness on college success and probabilities of college success for comparative analysis of university performance. In theory, there is an established assumption that college readiness affects college readiness. This is because students' college aptitudes significantly correlate with their college readiness. Positive university factors strengthen this relationship. However, the distortion of this relationship can represent the errors and mistakes in the education system.

For this reason, the ability to link the precollege preparedness level of students with their abilities to prepare and be ready for employment is the quality of HE. However, this is not adequate to make a UG a high performer. In addition to linking student abilities precisely, UGs should be able to enhance the probabilities of college success. This means that they should make their alumni competitive in the job market. The standardization of the effects of college readiness on college success and the probability of college success across institutions can be highly assured through standardization of the curriculum, teaching-learning, and degrees like that attempted in Europe. If the curriculum, the teaching-learning, the management, and other services show significant differences across institutions, the achievement of standardized measurement for comparative purposes may not be realized. Also, standardization is not 
adequate, and modeling a measurement for applied comparative purposes is highly warranted.

However, some factors may distort this relationship. These factors spread their roots in the education system in general and some of them can be institutional. The lower curriculum and teaching-learning standards that tolerate shallowness in learning; shortage of early warning assessment, and monitoring of student preparedness that simply passes students to higher learning may cause a voluntary and inevitable admission of unprepared students to HE. Especially, the problems in the assessment system contribute to the imbalances between students' CCGPAs and their abilities. The shortage of resources and trained teachers, and the students' motivation towards learning are some causes for unpreparedness.

\section{CONCLUSION}

Generally, there is an established assumption by decisionmakers in the selection, admission, and placement system around the world that those students who are screened for college learning through appropriate processes and placed in fields of study that match their interest and ability will also successfully complete their college learning and training. The contemporary decision theory in education, however, tends to take a pragmatic approach and mixes the assumption of all decision theories in practice.

In order to test this assumption in the Ethiopian context, this study tested the assumption that 'college readiness affects college success.' Although this study failed to reject this assumption, the model accounted for only 26 percent of the variance in college success. This means that 74 percent of the variance in college success is explained by other factors. The objective of this study was not only to study how college readiness affects college success; rather, the study was aimed at the meanings of these effects in the applied comparative sense. Firstly, when the conditional effect of college readiness on college success was compared across UGs and departments, a significant difference was observed. Secondly, the study found that the probability of college success at a value of college readiness significantly varied across UGs and departments. Thirdly, in a UG with the highest conditional effect of college readiness on college success, the lowest probability of college success at a value of college readiness is observed. This shows that maintaining a higher effect of college readiness on college success alone may not guarantee the effectiveness of a UG unless the UG simultaneously heightens the probability of college success.

The study also analyzed how this can be related to the quality of HE. Firstly, the study revealed that a UG which significantly promoted the effect of college readiness on college success is relatively more conservative and accurate in managing student learning. Secondly, awarding the highest CCGPA at the lowest conditional effect may show the poor quality of a UG. Also, maintaining a higher conditional effect of college readiness on college success without simultaneously promoting the probability of college success at a value of college readiness ends in poor performance of a UG. Therefore, maintaining a higher conditional effect of college readiness on college success while simultaneously heightening the probability of college success at a value of college readiness is a characteristic of high-performing UG.

The study recommends redesigning of college readiness depending on a rigorous curriculum and teaching-learning standards. To this end, the development of college readiness should be ensured through multidimensional early interventions, monitoring, and partnerships to develop student college readiness. The education system should redesign the college readiness models in line with the feasible and relevant expected outcomes and should monitor the assurance of the college readiness step by step from the early education years. For the reason that the college readiness level of college entering students is an input for $\mathrm{HE}$ quality, HE quality assessment should consider the college readiness variable as a covariate in HE quality assessment. In addition to the current multidimensional models of HE quality assessment, it is believed that the model used in this study can be a new additional input for the HE quality assessment system. This model also can be one of the models that use student university inputs, processes, and students' HE learning outcomes in HE quality assessment.

\section{ACKNOWLEDGEMENT}

We thank Addis Ababa University and Wachemo University for funding this research. Our gratitude also goes to the sample universities' presidents, registrar officers, lecturers, and students for active cooperation with the authors during the data collection. This funding was used for transportation, purchasing research equipment, paying for data collectors, printing and copying research materials.

\section{REFERENCES}

Allensworth, E. M. and Clark, K. (2020) 'High School GPAs and ACT Scores as Predictors of College Completion: Examining Assumptions About Consistency Across High Schools', Educational Researcher, Vol. 49, No. 3, pp. 198-211. https://doi. org/10.3102/0013189X20902110

Alonzo, D., Mirriahi, N. and Davison, C. (2019) 'The Standards for Academics' Standards-Based Assessment Practices', Assessment \& Evaluation in Higher Education, Vol. 44, No. 4, pp. 636 - 652. https://doi.org/10.1080/02602938.2018.15 $\underline{21373}$
Al-Twijri M. I. and Noaman A. Y. (2015) ‘A New Data Mining Model Adopted for Higher Institutions', Procedia Computer Science, Vol. 65, pp. 836-844.https://doi.org/10.1016/j.procs.2015.09.037

Arnold, J. C. (2018) 'An Integrated Model of Decision-Making in Health Contexts: The Role of Science Education in Health Education', International Journal of Science Education, Vol. 40, No. 5, pp. 519537. https://doi.org/10.1080/09500693.2018.1434721

Ary, D., Jacobs, L. C., Irvine, C. K. and Walker, D. (2018) Introduction to Research in Education, Boston: Cengage. 
Atkinson, R. C. and Geiser, S. (2009) 'Reflections on a Century of College Admission Tests', Educational Researcher, Vol. 38, No. 9, pp. 665-676. https://doi.org/10.3102/0013189x09351981

Balfanz, R. and Byrnes, V. (2019) 'Early Warning Indicators and Intervention Systems: State of the Field', in Fredricks, J. A., Reschly, A. L. and Christenson, S. L. (ed.) Handbook of student engagement interventions, Vol. 1, London: Academic Press.

Baron, J. (2004) 'Normative Models of Judgment and Decision Making', in Koehler, D. J., and Harvey, N. (ed.) Blackwell handbook of judgment and decision making, London: Blackwell.

Ben-Shakhar, G., Kiderman, I. and Beller, M. (1996) 'Comparing the Utility of Two Procedures for Admitting Students to Liberal Arts: An Application of Decision-Theoretic Models', Educational and Psychological Measurement, Vol. 56, No. 1, pp. 90-107. https:// doi.org/10.1177/0013164496056001006

Boud, D. (2017) 'Standards-Based Assessment for an Era of Increasing Transparency', in Carless, D., Bridges, S., Chan, C. and Glofcheski, R. (ed.) Scaling up Assessment for learning in higher education: The enabling power of assessment, Singapore: Springer. https://doi.org/10.1007/978-981-10-3045-1_2

Bridges, S.M., Wyatt-Smith, C.M., and Botelho, M.G. (2017) 'Clinical Assessment Judgments and 'Connoisseurship': Surfacing Curriculum-Wide Standards Through Transdisciplinary Dialogue', in Carless, D., Bridges, S., Chan, C. and Glofcheski, R. (ed.) Scaling up assessment for learning in higher education. The enabling power of assessment, Singapore: Springer. https:// doi.org/10.1007/978-981-10-3045-1_6

Brown, M., McNamara, G. and O'Hara, J. (2016) 'Quality and the Rise of Value-Added in Education: The Case of Ireland', Policy Futures in Education, Vol. 14, No. 6, pp. 810-829. https://doi. org/10.1177/1478210316656506

Callahan, R. M. and Hopkins, M. (2017) 'Policy Brief: Using ESSA to Improve Secondary English Learners' Opportunities to Learn through Course Taking', Journal of SchoolLeadership, Vol.27, No. 5, pp. 755-766. https://doi.org/10.1177/105268461702700507

Čechová, I., Neubauer J. and Sedlačík, M. (2019) ‘Tracking the University Student Success: Statistical Quality Assessment', Journal on Efficiency and Responsibility in Education and Science, Vol. 12, No. 1, pp. 12-25. http://dx.doi.org/10.7160/eriesj.2019.120102

Cho, K. W. and Serrano, D. M. (2020) 'Noncognitive Predictors of Academic Achievement Among Nontraditional and Traditional Ethnically Diverse College Students', The Journal of Continuing Higher Education, Vol. 68, No. 3, pp. 190-206. https://doi.org/1 $\underline{0.1080 / 07377363.2020 .1776557}$

Coates, H. (2009) 'What's the Difference? A Model for Measuring the Value Added by Higher Education in Australia', Higher Education Management and Policy, Vol. 21, No.1, pp. 1-20. https://doi.org/10.1787/hemp-v21-art5-en

Cohen, L., Manion, L. and Morrison, K. (2018) Research methods in education, $8^{\text {th }}$ edition, New York: Routledge.

Creswell, J. W. (2014) Research design: Qualitative, quantitative, and mixed methods approaches, Thousand Oaks: Sage.

Cunha, J. M. and Miller, T. (2014) 'Measuring Value-added in Higher Education: Possibilities and Limitations in the Use of Administrative Data', Economics of Education Review, Vol. 42, pp. 64-77. https://doi.org/10.1016/j.econedurev.2014.06.001

Davidson, J. C. (2015) 'Precollege Factors and Leading Indicators: Increasing Transfer and Degree Completion in a Community and Technical College System', Community College Journal of Research and Practice, Vol. 39, No. 11, pp. 1007-1021. https:// doi.org/10.1080/10668926.2014.919619
Ďurišová, M., Kucharčíková, A. and Tokarčíková, E. (2015) 'Assessment of Higher Education Teaching Outcomes (Quality of Higher Education)', Procedia - Social and Behavioral Sciences, Vol. 174, pp. 2497-2502. https://doi.org/10.1016/j. sbspro.2015.01.922

Edmonds, W. A. and Kennedy, T. D. (2018) An applied guide to research designs: Quantitative, qualitative, and mixed methods, Los Angeles: Sage.

Elqayam, S., and Evans, J. S. B. T. (2011) 'Subtracting "ought" from "is": Descriptivism versus normativism in the study of human thinking', Behavioral and Brain Sciences, Vol. 34, No. 5, pp. 233-248. https:// doi.org/10.1017/s0140525x1100001x

Fennie, T., Mayman, Y., van Louw, C., Useh, E. and Kombora, M. (2020) 'Psychosocial Factors Impacting the College Adjustment of Undergraduate Students: A Scoping Review', Journal of Psychology in Africa, Vol. 30, No. 2, pp. 105-96. https://doi.org/10.1080/143302 $\underline{37.2020 .1716548}$

Field, A. (2018) Discovering statistics using IBM SPSS statistics, London : Sage.

Fina, A. D., Dunbar, S. B. and Welch, C. J. (2018) 'Establishing Empirical Links between High School Assessments and College Outcomes: An Essential Requirement for College Readiness Interpretations', Educational Assessment, Vol. 23, No. 3, pp. 157-172. https://doi.org/ $\underline{10.1080 / 10627197.2018 .1481387}$

Galla, B. M., Shulman, E. P., Plummer, B. D., Gardner, M., Hutt, S. J., Goyer, J. P., D'Mello, S. K., Finn, A. S. and Duckworth, A. L. (2019) 'Why High School Grades are Better Predictors of On-Time College Graduation than are Admissions Test Scores: The Roles of Self-Regulation and Cognitive Ability', American Educational Research Journal, Vol. 56, No.6, pp. 2077-2115. https://doi. org/10.3102/0002831219843292

González Canché, M. S. (2019) 'Repurposing Standardized Testing for Educational Equity: Can Geographical Bias and Adversity Scores Expand True College Access?', Policy Insights from the Behavioral and Brain Sciences, Vol. 6, No. 2, pp. 225-235. https://doi. org/10.1177/2372732219861123

G-power for Windows, Version 3.1.9.6 (2020) Germany: Heinrich Heine University Düsseldorf. [software]

Gray, G., Mcguinness, C. and Owende, P. (2016) 'Non-Cognitive Factors of Learning as Early Indicators of Students at-Risk of Failing in Tertiary Education', in Khine, M. S. and Areepattamannil, S. (ed.) Non-cognitive skills and factors in educational attainment: Contemporary approaches to research in learning innovations, Rotterdam: SensePublishers. https://doi.org/10.1007/978-94-6300591-3 10

Hrnčiar, M. and Madzík, P. (2015) 'A 3D View of Issues of Quality in Higher Education', Total Quality Management \& Business Excellence, Vol. 28, No. 5-6, pp. 633-662. https://doi.org/10.1080/14783363.201 $\underline{5.1105100}$

Hsieh, F. Y., Bloch, D. A. and Larsen, M. D. (1998) 'A Simple Method of Sample Size Calculation for Linear and Logistic Regression', Statistics in Medicine, Vol. 17, No. 14, pp. 1623-1634. https://doi.org/10.1002/ (sici) 1097-0258(19980730)17:14<1623::aid-sim871>3.0.co;2-s

Hsieh, T. (2019) 'A Preliminary Study of Multiple College Admission Criteria in Taiwan: The Relationship among Motivation, Standardized Tests, High School Achievements, and College Success', Higher Education Research \& Development, Vol. 38, No. 4, pp. 762-779. https://doi.org/10.1080/07294360.2019.1586841

Hughes, P. (2006) Secondary education at the crossroads: International perspectives relevant to the Asia-Pacific region, Netherlands: Springer. 
Hughes, J. A. and Sharrock, W. W. (1997) The philosophy of social research, UK: Longman.

Jackson, J. and Kurlaender, M. (2014) 'College Readiness and College Completion at Broad Access Four-Year Institutions', American Behavioral Scientist, Vol. 58, No. 8, pp. 947-971. https://doi.org/10.1177/0002764213515229

Kallison, J. J. (2017) 'The Effects of an Intensive Postsecondary Transition Program on College Readiness for Adult Learners', Adult Education Quarterly, Vol. 67, No. 4, pp. 302-321. https://doi.org/10.1177/0741713617725394

Kemple, J., Segeritz, M. D. and Stephenson, N. (2013) 'Building On-Track Indicators for High School Graduation and College Readiness: Evidence from New York City', Journal of Education for Students Placed at Risk, Vol. 18, No. 1, pp. 7-28. https://doi.org/10.1080/10824669.2013.747945

Kim, J. S. and Sunderman, G. L. (2005) 'Measuring Academic Proficiency under the No Child Left Behind Act: Implications for Educational Equity', Educational Researcher, Vol. 34, No. 8, pp. 3-13. https://doi. org $/ 10.3102 / 0013189 \times 034008003$

Klarin, M. V. (2016) Twenty-First Century Educational Theory and the Challenges of Modern Education: Appealing to the Heritage of the General Teaching Theory of the Secondary Educational Curriculum and the Learning Process', Russian Education \& Society, Vol. 58, No. 4, pp. 299-312. https://doi.org/10.1080/10609393.2016.1250510

Kowalski, T. J. (2008) 'Evidence and Decision Making in Professions', in Kowalski, T. J. and Lasley, T. J. (ed.) Handbook of Data-Based Decision Making in Education (First edition). New York: Routledge. https://doi.org/10.4324/9780203888803

Leeds, D. M., and Mokher, C. G. (2019) 'Improving Indicators of College Readiness: Methods for Optimally Placing Students into Multiple Levels of Postsecondary Coursework', Educational Evaluation and Policy Analysis, Vol. 42, No. 1, pp.87-109. https://doi. org/10.3102/0162373719885648

Lehman, N. (1999) The big test: The secret history of the American meritocracy, New York: Farrar, Straus \& Giroux.

Liu, O. L. (2011) 'Measuring Value-added in Higher Education: Conditions and Caveats - Results from Using the Measure of Academic Proficiency and Progress (MAPPTM)', Assessment \& Evaluation in Higher Education, Vol. 36, No. 1, pp. 81-94. https://doi. org/10.1080/02602930903197917

Lunceford, C., Sondergeld, T.A. and Stretavski, E. L. (2017) 'AComparative Case Study of Student Preparation for Postsecondary Education: How GEAR UP, Socioeconomic Status, and Race Influence Academic and Non-academic Factors', Journal of Education for Students Placed at Risk (JESPAR), Vol. 22, No. 4, pp. 185 - 199. https://doi.org/10.1080/ $\underline{10824669.2017 .1364643}$

March, J. G. (1978) 'Bounded Rationality, Ambiguity, and the Engineering of Choice', Bell Journal of Economics, Vol. 9, No. 2, pp. 587-608. https://doi.org/10.2307/3003600

Martin, L. and Mahat, M. (2017) 'The Assessment of Learning Outcomes in Australia: Finding the Holy Grail', AERA Open, Vol. 3, No. 1, pp. 1-19. https://doi.org/10.1177/2332858416688904

Martín-García, A.V., Martínez-Abad, F., and Reyes-González, D. (2019) 'TAM and stages of adoption of blended learning in education by application of data mining techniques', British Educational Research Association, Vol. 50, No. 5, pp. 2484-2500. https://doi.org/10.1111/ bjet. 12831

McFall, J. P. (2015) 'Rational, Normative, Descriptive, Prescriptive, or Choice Behavior? The Search for Integrative Metatheory of Decision Making', Behavioral Development Bulletin, Vol. 20, No. 1, pp. 45-59. https://doi.org/10.1037/h0101039
Means, B., Wang, H., Young, V., Peters, V. and Lynch, S. (2016) 'STEM-focused High Schools as a Strategy for Enhancing Readiness for Postsecondary STEM Programs', Journal of Research in Science Teaching, Vol. 53, No. 5, pp. 709-736. https://doi.org/10.1002/tea.21313

Menard, S. (1995) Applied logistic regression analysis. Sage university paper series on quantitative applications in the social sciences, Thousand Oaks: Sage.

Ministry of Education (2009) Ethiopian education and training policy, Addis Ababa: Ministry of Education.

Mokher, C.G. and Leeds, D.M. (2019) 'Can a College Readiness Intervention Impact Longer-Term College Success? Evidence from Florida's Statewide Initiative', The Journal of Higher Education, Vol. 90, No. 4, pp. 585-619. https://doi.org/10.1 $\underline{080 / 00221546.2018 .1525986}$

Nagle, K., Newman, L. A., Shaver, D. M. and Marschark, M. (2016) 'College and Career Readiness: Course Taking of Deaf and Hard of Hearing Secondary School Students', American annals of the deaf, Vol. 160, No. 5, pp. 467-482. https://doi.org/10.1353/aad.2016.0000

NEAEA (2019) NEAEA - Ethiopia National Educational Assessment and Examinations Agency, [online], Available: https://www.neaea.gov.et/ [22 Mar 2020].

Niu, S. X. and Tienda, M. (2010) 'The Impact of the Texas Top Ten Percent Law on College Enrollment: A Regression Discontinuity Approach', Journal of Policy Analysis and Management, Vol. 29, No. 1, pp. 84-110. https://doi. org/10.1002/pam.20480

Noaman, A. Y., Ragab, A. M., Madbouly, A. I., Khedra, A., and Fayoumi, A. (2017) 'Higher Education Quality Assessment Model: Towards Achieving Educational Quality Standard', Studies in Higher Education, Vol. 42, No. 1, pp. 23-46. https://doi.org/10.1080/03075079.2015.1034262

Olani, A. (2017) 'Predicting First Year University Students' Academic Success', Electronic Journal of Research in Education Psychology, Vol. 7, No. 19., pp. 1053-1072. https://doi.org/10.25115/ejrep.v7i19.1351

Otavová, M., and Sýkorová, I. (2016) 'Differences in Results Obtained by Students of Different Faculties', Journal on Efficiency and Responsibility in Education and Science, Vol. 9, No. 1, pp. 1-6. https://doi.org/10.7160/eriesj.2016.090101

Raiffa, H. (1994) 'The Prescriptive Orientation of Decision Making: A Synthesis of Decision Analysis, Behavioral Decision Making, and Game Theory', in Ríos, S. (ed.) Decision Theory and Decision Analysis: Trends and Challenges. Dordrecht: Springer. https://doi.org/10.1007/978-94-0111372-4_1

Rasinski, T. V., Chang, S., Edmondson, E., Nageldinger, J., Nigh, J. L., Remark, L., Kenney, K. S., Walsh-Moorman, E., Yildirim, K., Nichols, W., Paige, D. and Rupley, W. H. (2017) 'Reading Fluency and College Readiness', Journal of Adolescent \& Adult Literacy, Vol. 60, No. 4, pp. 453-460. https://doi.org/10.1002/jaal.559

Rattani, S. A. (2016) 'SAT: Does Racial Bias Exist?', Creative Education, Vol. 7, No. 15, pp. 2151-2162. https://doi. org/10.4236/ce.2016.715213

Relles, S. R. (2016) 'Rethinking Postsecondary Remediation: Exploring an Experiential Learning Approach to College Writing', The Journal of Continuing Higher Education, Vol. 64, No. 3, pp. 172-180. https://doi.org/10.1080/07377363.2 $\underline{016.1229115}$ 
Sava, S., Borca, C. and Danciu, L. (2014) 'Models of Quality Assurance in Evaluation and Validation of Competencies, for an Easier Access to Higher Education', Procedia - Social and Behavioral Sciences, Vol. 142, pp. 176-182. https://doi. org/10.1016/j.sbspro.2014.07.640

Savitz-Romer, M. and Rowan-Kenyon, H.T. (2020) 'Noncognitive Skills, College Success, and Career Readiness: What Matters and to Whom?', About Campus: Enriching the Student Learning Experience, vol. 25, No. 1, pp. 4-13. https://doi. org/10.1177/1086482220906161

Sawyer, R. (1996) 'Decision Theory Models for Validating Course Placement Tests', Journal of Educational Measurement, Vol. 33, No. 3, pp. 271-290. https://doi.org/10.1111/j.1745-3984.1996. tb00493.x

Saygin, P. O. (2020) 'Gender Bias in Standardized Tests: Evidence from A Centralized College Admissions System', Empirical Economics, Vol. 59, pp. 1037-1065. https://doi.org/10.1007/ $\underline{\mathrm{s} 00181-019-01662-\mathrm{Z}}$

Shavelson, R., Domingue, B., Mariño, J. P., Mantilla, A. M., Forero, A. M. and Wiley, E. E. (2016) 'On the Practices and Challenges of Measuring Higher Education Value Added: The Case of Colombia', Assessment \& Evaluation in Higher Education, Vol. 41, No. 5, pp. 695-720. https://doi.org/10.1080/02602938.2016. $\underline{1168772}$

Shewach, O. R., Shen, W., Sackett, P. R. and Kuncel, N. R. (2017) 'Differential Prediction in the Use of the SAT and High School Grades in Predicting College Performance: Joint Effects of Race and Language', Educational Measurement: Issues and Practice, Vol. 36, No. 3, pp. 46-57. https://doi.org/10.1111/emip.12150

Sønderlund, A. L., Hughes, E. and Smith, J. (2019) 'The Efficacy of Learning Analytics Interventions in Higher Education: A Systematic Review', British Journal of Educational Technology, Vol. 50, No. 5, pp. 2594-2618. https://doi.org/10.1111/bjet.12720

Tasopoulou, K. and Tsiotras, G. (2017) 'Benchmarking Towards Excellence in Higher Education', Benchmarking: An International Journal, Vol. 24, No. 3, pp. 617-634. https://doi. org/10.1108/BIJ-03-2016-0036

Tierney, W.G. and Duncheon, J. C. (2015) The Problem of College Readiness, New York: University of New York press.

Trines, S. (2018) Education System Profiles: Education in Ethiopia, [online], Available: https://wenr.wes.org/2018/11/education-inethiopia [15 Aug 2020].
Tucker, L. and McKnight, O. (2019) 'Assessing the Validity of College Success Indicators for the At-Risk Student: Toward Developing a Best-Practice Model', Journal of College Student Retention: Research, Theory \& Practice, Vol. 21, No. 2, pp. 166 183. https://doi.org/10.1177/1521025117696822

Turner, L. A. and Angulo, A. J. (2018) 'Risky Business: An Integrated Institutional Theory for Understanding High-Risk Decision Making in Higher Education', Harvard Educational Review, Vol. 88, No. 1, pp. 53-80. https://doi.org/10.17763/1943-5045$\underline{88.1 .53}$

van der Linden, W. J. (1991) 'Applications of Decision Theory to TestBased Decision Making', In: Hambleton, R.K. and Zaal, J.N. (ed.) Advances in educational and psychological testing: theory and applications. Evaluation in education and human services series, vol 28, Dordrecht: Springer. https://doi.org/10.1007/97894-009-2195-5 5

van der Linden, W.J. (1996) 'Decision Theory in Educational Testing', in Keeves, J. P. (ed.) Educational research, methodology and measurement: An international handbook (2nd edition), pp. 725730, Oxford: Pergamon Press.

Wang, P. (1996) 'Heuristics and Normative Models of Judgment under Uncertainty', International Journal of Approximate Reasoning, Vol. 14, No. 4, pp. 221-235. https://doi.org/10.1016/0888$\underline{613 \times(95) 00091-t}$

Wang, X. (2017) 'Toward a Holistic Theoretical Model of Momentum for Community College Student Success', in Paulsen, M. (ed.) Higher education: Handbook of theory and research, Cham: Springer. https://doi.org/10.1007/978-3-319-48983-4_6

Wariyo, L. G. (2020) 'Higher Education Quality Assessment in Ethiopia: A Comparative Study', Multidisciplinary Journal for Education, Social and Technological Sciences, Vol. 7, No. 1, pp. 1-31. https://doi.org/10.4995/muse.2020.10512

Xu, D., Solanki, S. and Harlow, A. (2020) 'Examining the Relationship Between 2-year College Entry and Baccalaureate Aspirants' Academic and Labor Market Outcomes: Impacts, Heterogeneity, and Mechanisms', Research in Higher Education, Vol. 61, No. 3, pp. 297-329. https://doi.org/10.1007/s11162-019-09559-7

Zlatkin-Troitschanskaia, O., Pant, H. A. and Coates, H. (2016) 'Assessing Student Learning Outcomes in Higher Education: Challenges and International Perspectives', Assessment \& Evaluation in Higher Education, Vol. 41, No. 5, pp. 655-661. https://doi.org/10.1080/02602938.2016.1169501 


\begin{tabular}{|c|c|c|c|c|c|c|c|}
\hline $\begin{array}{l}\text { EHEEE } \\
\text { Score }\end{array}$ & UG & Department & $z$ & Prob. & $p$ Level & Sum $p$ level & Sum $p$ Level Total \\
\hline 355.00 & 1 & 1 & -1.24 & .22 & 0 & & \multirow{9}{*}{14} \\
\hline 398.00 & 1 & 1 & -.42 & .40 & 0 & 1 & \\
\hline 435.68 & 1 & 1 & .29 & .57 & 1 & & \\
\hline 355.00 & 1 & 2 & .11 & .53 & 1 & & \\
\hline 398.00 & 1 & 2 & 3.30 & .96 & 3 & 7 & \\
\hline 435.68 & 1 & 2 & 6.10 & 1.00 & 3 & & \\
\hline 355.00 & 1 & 3 & -.21 & .45 & 0 & & \\
\hline 398.00 & 1 & 3 & 1.43 & .81 & 3 & 6 & \\
\hline 435.68 & 1 & 3 & 2.87 & .95 & 3 & & \\
\hline 355.00 & 2 & 1 & -.58 & .36 & 0 & & \multirow{9}{*}{20} \\
\hline 398.00 & 2 & 1 & .32 & .58 & 1 & 4 & \\
\hline 435.68 & 2 & 1 & 1.10 & .75 & 3 & & \\
\hline 355.00 & 2 & 2 & .78 & .68 & 2 & & \\
\hline 398.00 & 2 & 2 & 4.04 & .98 & 3 & 8 & \\
\hline 435.68 & 2 & 2 & 6.90 & 1.00 & 3 & & \\
\hline 355.00 & 2 & 3 & .45 & .61 & 2 & & \\
\hline 398.00 & 2 & 3 & 2.17 & .90 & 3 & 8 & \\
\hline 435.68 & 2 & 3 & 3.68 & .98 & 3 & & \\
\hline 355.00 & 3 & 1 & -.44 & .39 & 0 & & \multirow{9}{*}{19} \\
\hline 398.00 & 3 & 1 & .19 & .55 & 1 & 3 & \\
\hline 435.68 & 3 & 1 & .74 & .68 & 2 & & \\
\hline 355.00 & 3 & 2 & .91 & .71 & 2 & & \\
\hline 398.00 & 3 & 2 & 3.91 & .98 & 3 & 8 & \\
\hline 435.68 & 3 & 2 & 6.54 & 1.00 & 3 & & \\
\hline 355.00 & 3 & 3 & .59 & .64 & 2 & & \\
\hline 398.00 & 3 & 3 & 2.04 & .89 & 3 & 8 & \\
\hline 435.68 & 3 & 3 & 3.31 & .96 & 3 & & \\
\hline
\end{tabular}

Note: If prob <.50, p level = 0; If $.50<=$ prob. $<.61, p$ level $=1 ;$ If $.61<=$ prob $>.75, p$ level $=2 ;$ If prob $>=.75, p$ level $=3$ prob. $=p-$ value, $N=551$

Appendix 1: The probability of college success at values of Moderators

\begin{tabular}{|c|c|c|c|c|c|c|c|c|}
\hline & \multirow{2}{*}{ B } & \multirow{2}{*}{ Se. } & \multirow{2}{*}{$d f$} & \multirow{2}{*}{$p$} & \multirow{2}{*}{$\operatorname{Exp}(B)$} & \multicolumn{2}{|c|}{ 95\% C.I.for $\operatorname{EXP}(B)$} \\
\hline & & & & & & & Lower & Upper \\
\hline \multirow[t]{5}{*}{ Step $1^{\text {a }}$} & EHEEE Score & -.23 & .23 & 1 & .31 & .79 & .51 & 1.24 \\
\hline & EGESLCE GPA & 13.98 & 8.15 & 1 & .09 & 1173837.56 & .14 & 1.02 \\
\hline & $\begin{array}{l}\text { EHEEE Score by Log Transfornation for } \\
\text { EHEEE Score }\end{array}$ & .03 & .03 & 1 & .29 & 1.04 & .97 & 1.10 \\
\hline & $\begin{array}{l}\text { EGESLCE GPA by Log Transfornation } \\
\text { for EGESLCE GPA }\end{array}$ & -6.02 & 3.88 & 1 & .12 & .00 & .00 & 4.79 \\
\hline & Constant & -11.28 & 13.95 & 1 & .42 & .00 & & \\
\hline
\end{tabular}

$p<.05 ; N=551$

Appendix 2: Linearity assumption checking for the binomial logistic regression 


\begin{tabular}{c|c|c|c}
\multicolumn{3}{c}{ Coefficients $^{\mathrm{a}}$} \\
\multirow{2}{*}{1} & Model & \multicolumn{2}{|c}{ Collinearity Statistics } \\
\cline { 2 - 4 } & Tolerance & VIF \\
\cline { 2 - 4 } & UG & .917 & 1.091 \\
\hline & Dpt & .722 & 1.386 \\
\cline { 2 - 4 } & EHEEE & .413 & 2.420 \\
\cline { 2 - 4 } & EGESLE & .551 & 1.816 \\
\hline
\end{tabular}

a. Dependent Variable: CCGPA; $N=551$

Appendix 3: Multicollinearity assumption check 